\title{
Morphometric and Physical Characterization of Borana Indigenous Goats in Southern Oromia, Ethiopia
}

\author{
Zewdu Edea Bedada ${ }^{1}$, Bikila Negasa Gilo,", Gurmessa Terfa Debela ${ }^{2}$ \\ ${ }^{1}$ Department of Animal Science, Chungbuk National University, Cheongju 28644, South Korea \\ ${ }^{2}$ Oromia Agricultural Research Institute, Yabello Pastoral and Dryland Agriculture Research Center, Ethiopia
}

Copyright@2019 by authors, all rights reserved. Authors agree that this article remains permanently open access under the terms of the Creative Commons Attribution License 4.0 International License

\begin{abstract}
The study was conducted in Borana zone of southern Ethiopia to phenotypically characterize Borana goats kept under pastoral and agro-pastoral management systems. In total, 257 of goats comprising of 199 female and 58 male goats were used for the study. Qualitative descriptions of the breed showed that sampled animals displayed high frequency for plain coat pattern (82.10\%) and white coat color (89.88\%). In both sexes, toggle was manifested in $6 \%$ of the animals. Nearly, $48 \%$ of the animal sampled (male and female) were polled. The overall body weight (BW), chest girth (CG), body length (BL), wither height (HW), pelvic width (PW), body condition score (BCS) and ear length (EL) for female goats were $27.99 \mathrm{~kg}, 64.34 \mathrm{~cm}, 69.60 \mathrm{~cm}, 66.64 \mathrm{~cm}, 14.35 \mathrm{~cm}, 2.87$ and 14.35, respectively. Within females, dentition significantly affected $(\mathrm{P}<0.001)$ body weight and all linear measurements $(\mathrm{P}>0.05)$. Similarly, dentition had significantly $(\mathrm{P}<0.001)$ influenced live body weight and other linear measurements in male goats. This study insight that Borana goats are superior to other indigenous goat breeds in many of the quantitative traits considered. Most of the parameters considered had positive and significant correlation with live body weight. Considering ease of measurement, chest girth (CG) could be used in performance recordings and bridge the gaps still present in keeping the performance of the breed to facilitate within breed selection scheme.
\end{abstract}

Keywords Borana Goats, Linear Measurement, Body Weight

\section{Highlights}

- Dentition significantly affected body weight and all linear measurements in both sexes

- Borana goats are superior to other indigenous goat breeds in many of the quantitative traits.
- Most of the parameters considered had positive and significant correlation with live body weight.

\section{Introduction}

The better adaption of goats to the arid- and semi- arid environments, high prolificacy and short generation interval [1] make them suitable for resource poor farming and pastoral communities. Under the climate change scenario and shift from savanna to bush encroached grazing lands, the contribution of goat is immense than ever before. The Borana goats are distributed in south and southeast of Ethiopia, adapted to arid and semi- arid environments have potential for better meat production and quality, fast growth rate and large body size [2, 3]. Presently, due to the high demand both at domestic and foreign markets for goat meat; there is a great opportunity for producers to exploit the growing market demands. Lack of information on breed characteristics may leads to underutilization and miss use of the resources. Despite the significant contribution of goats to the rural livelihoods and national economy; research and developments initiatives are by large at its infancy. Goat improvement programs if any in Ethiopia were mainly depend on the notion to improve productivity particularly milk yield through crossing of indigenous breeds with imported improved dairy goat breeds without critical consideration of the farmers preference and prevailing farming systems. Unfortunately, those attempts were ended with insignificant impact both at the genotype and household level due to incompatibility of the genotype with the production system [4]. There is a growing concern of genetic erosion of indigenous livestock breeds adapted to the low input productions systems [5] from replacement by high-input demanding breeds. In Ethiopia, there have been on-going initiatives to upgrade growth performance of locally adapted goat breeds through crossing with imported Boer goats including in the pastoral envir

onments where exotic breeds are hardly survive. 
Improving the production levels of adaptive breeds and in-situ utilization are central to the better management and conservation of farm animals' genetic resources. The unique genetic merit of adaptive breeds potentially contributes to the current and future production traits. Effective management of farm animal genetic resources requires comprehensive knowledge of the breed characteristics, including physical descriptions, geographical distribution and the production environments. Phenotypic breed or population characterization is the first step in the breed description and identification and useful in the classification of the populations, strains or breeds within a species [6]. Lack of information on breed characteristics may leads to underutilization and miss use of the resources (replacement and genetic dilution). Therefore, this study was aimed to phenotypically characterize Borana goats kept under pastoral and agro-pastoral management systems.

\section{Materials and Methods}

\subsection{Description of the Study Areas}

The Borana lowland is usually known as the southern rangelands. The rangeland lies west of Genale River and east of the Segan River. The southern limit of the rangeland goes up to the Ethio-Somali and Ethio-Kenyan borders, its northern limit is bounded by the cultivated lands, and Jemjem high forests [20]. It extends approximately between $4^{\circ} 3^{\prime} \mathrm{N}$ to $5 \mathrm{~N}$ and $37^{\circ} 4^{\prime} \mathrm{E}$ to $38^{\circ} 2^{\prime} \mathrm{E}$ with a total area of approximately $95,000 \mathrm{~km}^{2}$. This study focused on two districts namely Yabello and Dire. The landscape is slightly undulating that ranges in altitude from 1000 to 1500 meter above sea level (masl), having picks up to 2000 masl [21].

The rainfall of the area is distinctly bimodal pattern, viz. the main rainy season (Ganna) occurring from March to May which accounts 59\% of the total rainfall of the area, and the short and small rainy season (Hagayya) which occurs in months from September to November that accounts $27 \%$ of the total rainfall of the study area. Droughts are common once every 5-10 years [21]. A prominent feature of the Borana ecosystem is the erratic and variable nature of the rainfall, with most areas receiving between $238 \mathrm{~mm}$ and $896 \mathrm{~mm}$ annually, with a high coefficient of variability ranging from $18 \%$ to $69 \%$ [22]. Seasonal distribution of rainfall is more important than the annual total rainfall in influencing forage production from rangelands. Shortages of forages occur during periods of low rainfall leading to lower livestock productivity and higher production losses.

Livestock production is the mainstay of the pastoral and agro-pastoral communities of the Borana people. The major livestock reared are cattle, camels, goats and sheep. The best forage sources are native species of grasses, woody plants and stands of Acacia. Most of these plants have many uses such as human food, medicines for human and animals, construction materials and other cultural purposes [23].

\subsection{Sampling and Data Collection}

In total, 257 of goats comprising of 199 female and 58 male goats were sampled from two representative districts of Borana zone; namely Yabello and Dire. These two sample districts were selected purposively based on the presence of relatively large number of goat population. Since there was hardly any record kept by the pastoralists, the sampled goats were categorized based on dentition as full milk teeth (OPPI), 1 pair of permanent incisors (1PPI), 2 pairs of permanent incisors (2PPI), 3 pairs of permanent incisors (3PPI) and 4 pairs of permanent incisors (4PPI) following [7]. Body condition score (BCS) was assessed subjectively and scored using the 5 point scale $(1=$ very thin, $2=$ thin, $3=$ average, $4=$ fat and $5=$ Very fat $/$ obese) for both sexes according to [8]. The qualitative variables recorded via visual observation included: coat pattern, coat color type, head profile, ear orientation, presence, or absence of toggle, beard and wattle. Linear measurements were recorded using tape measure in $\mathrm{cm}$. Continuous traits measured were body length (BL), chest girth (CG), height at wither (HW), pelvic width (PW) and ear length (EL). Scrotal circumference (SC) was also measured. The live body weight (BW) was measured using a spring balance. Body length refers to the distance from the base of the neck (first thoracic vertebrae) to the base of the tail (where it joins the body. Chest girth measures the distance from the backbone at the shoulder to the brisket between the front legs. Height at wither measures the distance from the surface of a platform on which the animal stands to the withers. Pelvic width is the distance between the outer edges of the major hip bones on the right and left side. Ear length is the length between the bases of the ears attached to the head and ending edges of the ears. Scrotal circumference is the length around the two testicles of male goats.

\section{Statistical Analysis}

Live body weight, linear body measurements and qualitative parameters of the animals were coded into spreadsheets. Quantitative data were analyzed using SAS (9) using the General Linear Model (GLM) procedure. The effects of class variables were expressed as Least Square Means (LSM) \pm SE. Means were separated using Turkey Karamers. Due to the low number of males in each dentition class, analysis was done for both sexes independently. Within each sex, dentition was fitted as fixed factors. Correlations (Pearson's correlation coefficient) between body measurements were computed 
for males and females. The stepwise regression procedure of SAS [9] was used to determine the relative importance of live-animal body measurements in a model designed to predict body weight. Live weight was regressed on the body measurements separately for both sexes. Due to inadequate sample size of males in 0 and 1 dentition classes, 0 and 1 were pooled together. The choice of the best fitted regression model was assessed using coefficient of determination $\left(\mathrm{R}^{2}\right)$.

\section{Model used for the dentition effect was:}

$$
\mathrm{Y}_{\mathrm{ij}}=\mu+\mathrm{D}_{\mathrm{i}}+\mathrm{e}_{\mathrm{ij}}
$$

Where: $\mathrm{Y}_{\mathrm{ij}}=$ Observed body weight or linear measurements

$\mu=$ Overall mean

$\mathrm{D}_{\mathrm{i}}=$ the fixed effect of ith dentition classes ( $\mathrm{i}=0$-1PPI, 2PPI, 3PPI, 4PPI)

$$
e_{i j}=\text { random error }
$$

\section{Model used for the sex effect was:}

$$
\mathrm{Y}_{\mathrm{ij}}=\mu+\mathrm{S}_{\mathrm{i}}+\mathrm{e}_{\mathrm{ij}}
$$

Where: $Y_{i j}=$ Observed body weight or linear measurements

$\mu=$ Overall mean

$D_{i}=$ the fixed effect of ith sex classes $(i=$ Female and Male)

$e_{i j}=$ random error

\section{Multiple linear regression models for adult females}

$$
Y_{j}=\beta_{0}+\beta_{1} X_{1}+\beta_{2} X_{2}+\beta_{3} X_{3}+\beta_{4} X_{4}+\beta_{5} X_{5}+e j
$$

Where:

$Y_{j}=$ the dependent variable body weight; $\beta_{0}=$ the intercept; $X_{1}, X_{2}, X_{3}, X_{4}$ and $X_{5}$ are the independent variables such as body length, chest girth, height at wither, pelvic width and body condition score, respectively.

$\beta_{1}, \beta_{2}, \beta_{3}, \beta_{4}$ and $\beta_{5}$ are the regression coefficient of the variable $\mathrm{X}_{1}, \mathrm{X}_{2}, \mathrm{X}_{3}, \mathrm{X}_{4}$ and $\mathrm{X}_{5}$, respectively

$e_{j}=$ the residual error

\section{Multiple linear regression models for males}

$$
Y_{j}=\beta_{0}+\beta_{1} X_{1}+\beta_{2} X_{2}+\beta_{3} X_{3}+\beta_{4} X_{4}+\beta_{5} X_{5}+\beta_{6} X_{6}+e_{j}
$$

Where:

$Y_{j}=$ the dependent variable body weight; $\beta_{0}=$ the intercept; $X_{1}, X_{2}, X_{3}, X_{4}, X_{5}$ and $X_{6}$ are the independent variables such as body length, chest girth, height at wither, pelvic width, scrotal circumference and body condition score, respectively.

$\beta_{1}, \beta_{2}, \beta_{3}, \beta_{4}, \beta_{5}$, and $\beta_{6}$ are the regression coefficient of the variable $\mathrm{X}_{1}, \mathrm{X}_{2}, \mathrm{X}_{3}, \mathrm{X}_{4}, \mathrm{X}_{5}$, and $\mathrm{X}_{6}$, respectively.

$$
e_{j}=\text { the residual error }
$$

\section{Results and Discussion}

\subsection{Qualitative Traits of Goats}

Qualitative characteristics of Borana goats are presented in Table 1. The breed showed high frequency for plain coat pattern (82.10\%) and white coat color (89.88\%). Mixed coat colors have the lowest frequencies among the sampled goats (17.90\%). Results on coat colors revealed that the breed is predominately uni-colored. This is an indication that the Borana breed of goats have been become uniform in coat color through selective breeding and environmental adaptation. The higher proportion of animals with white coat colors in the present study appears to be an adaptation to the pronounced seasonal fluctuations in the intensity and duration of light and heat in this area. Coat color is important for the regulation of physiological processes and the adaptation of animals to particular ecological conditions $[10,11]$. In both sexes, toggle was manifested in $6 \%$ of the animals. Nearly, $48 \%$ of the animal sampled (male and female) were polled and had a very noticeable property towards semi- dropping ears. Straight head profile was most frequent among the sampled animals.

\subsection{Quantitative Traits of Goats}

Live body weight and linear body measurements for female and male Borana goats are summarized in Table 2 and 3, respectively. The overall body weight (BW), chest girth (CG), body length ( $\mathrm{BL}$ ), height at wither (HW), pelvic width (PW), body condition score (BCS) and ear length (EL) for female goats were $27.99 \mathrm{~kg}, 64.34 \mathrm{~cm}$, $69.60 \mathrm{~cm}, 66.64 \mathrm{~cm}, 14.35 \mathrm{~cm}, 2.87$ and $14.35 \mathrm{~cm}$, respectively. Body weight, height at wither, chest girth and ear length of $31.80 \mathrm{~kg}, 69.4 \mathrm{~cm}$. $74.4 \mathrm{~cm}$ and $14.60 \mathrm{~cm}$ were reported for adult female of the same breed [2]. The value obtained for ear length is higher than for Afar, Abergele, Woyto-Guji and Harerghe highland goats [2]. Similarly, Borana goats are taller than most of indigenous goat breeds except the Nubia and Barka goats. This study indicated that Borana goats are superior to other indigenous goat breeds in many of the quantitative traits considered. Within females, dentition significantly affected $(P<0.001)$ body weight and all linear measurements $(\mathrm{P}>0.05)$. Animals in dentition 3 and 4 had higher records than their counterpart at 1 and 2 dentition groups. Similarly, dentition had significantly $(\mathrm{P}<0.001)$ influenced live body weight and other linear measurements in male goats. The linear body measurements increased as animal advances with age regardless of sex. This was in consonance with the report of [18]. A significant effect of age is also reported by [19] who shows the effect of age on BW and other body measurements in different goat breeds of Ethiopia.

The average adult body weight of Borana bucks was higher than the average body weight of Afar bucks (31 kg), Abergele bucks (33kg) and Woyto-Guji bucks (39 kg) [2]. 
Table 1. Qualitative characteristics of Borana goats

\begin{tabular}{|c|c|c|c|c|c|c|c|}
\hline \multirow{3}{*}{ Traits } & \multirow{3}{*}{ Attribute } & \multicolumn{4}{|c|}{ Sex } & \multirow{2}{*}{\multicolumn{2}{|c|}{ Total }} \\
\hline & & \multicolumn{2}{|c|}{ Female } & \multicolumn{2}{|c|}{ Male } & & \\
\hline & & No. & $\%$ & No. & $\%$ & No & $\%$ \\
\hline \multirow{4}{*}{ Coat color pattern } & Plain & 163 & 81.91 & 48 & 82.76 & 211 & 82.1 \\
\hline & Patchy & 32 & 16.08 & 9 & 15.52 & 41 & 15.95 \\
\hline & Spotted & 4 & 2.01 & 1 & 1.72 & 5 & 1.95 \\
\hline & Overall & 199 & 100 & 58 & 100 & 257 & 100 \\
\hline \multirow{6}{*}{ Coat color type } & White & 180 & 90.45 & 51 & 87.93 & 231 & 89.88 \\
\hline & Brown & 6 & 3.02 & 1 & 1.72 & 7 & 2.72 \\
\hline & Black & 5 & 2.51 & 1 & 1.72 & 6 & 2.33 \\
\hline & Gray & 7 & 3.52 & 3 & 5.17 & 10 & 3.89 \\
\hline & White and black with black dominant & 1 & 0.5 & 1 & 1.72 & 2 & 0.78 \\
\hline & White and black with white dominant & 0 & 0 & 1 & 1.72 & 1 & 0.39 \\
\hline \multirow{3}{*}{ Head profile } & Straight & 192 & 96.48 & 56 & 98.25 & 248 & 96.88 \\
\hline & Slightly convex & 7 & 3.52 & 1 & 1.75 & 8 & 3.13 \\
\hline & Overall & 199 & 100 & 57 & 100 & 256 & 100 \\
\hline \multirow{3}{*}{ Toggle } & Present & 13 & 6.53 & 3 & 5.17 & 16 & 6.23 \\
\hline & Absent & 186 & 93.47 & 55 & 94.83 & 241 & 93.77 \\
\hline & Overall & 199 & 100 & 58 & 100 & 257 & 100 \\
\hline \multirow{3}{*}{ Beard } & Present & 21 & 10.55 & 30 & 51.72 & 51 & 19.84 \\
\hline & Absent & 178 & 89.45 & 28 & 48.28 & 206 & 80.16 \\
\hline & Overall & 199 & 100 & 58 & 100 & 257 & 100 \\
\hline \multirow{4}{*}{ Ear form } & Horizontal & 113 & 57.07 & 28 & 48.28 & 141 & 55.08 \\
\hline & Semi-pendulous & 82 & 41.41 & 29 & 50 & 111 & 43.36 \\
\hline & Dropping & 3 & 1.52 & 1 & 1.72 & 4 & 1.56 \\
\hline & Overall & 198 & 100 & 58 & 100 & 256 & 100 \\
\hline
\end{tabular}

Table 2. Live weight and linear measurements of the different age groups in female Borana goats

\begin{tabular}{ccccccccc}
\hline Effect & $\mathrm{N}$ & BW(kg) & BL $(\mathrm{cm})$ & CG $(\mathrm{cm})$ & HW(cm) & EL $(\mathrm{cm})$ & BCS & PW(cm) \\
\hline Overall & 199 & $27.99 \pm 1.12$ & $64.34 \pm 1.06$ & $69.6 \pm 1.15$ & $66.64 \pm 0.06$ & $14.35 \pm 0.08$ & $2.87 \pm 0.01$ & $14.35 \pm 0.02$ \\
\hline $\mathrm{R}^{2}$ & & 62.63 & 62.21 & 66.75 & 48.64 & 8.61 & 2.43 & 8.61 \\
\hline $\mathrm{CV}$ & & 17.67 & 6.1 & 6.18 & 5.66 & 12.57 & 14.94 & 12.57 \\
\hline Dentition & $* *$ & $* *$ & $* *$ & $* * *$ & $*$ & $\mathrm{~ns}$ & $* *$ \\
\hline 0 & 39 & $18.43 \pm 0.12^{\mathrm{d}}$ & $56.34 \pm 2.54^{\mathrm{d}}$ & $59.74 \pm 2.58^{\mathrm{d}}$ & $59.74 \pm 2.35^{\mathrm{c}}$ & $13.45 \pm 0.18^{\mathrm{c}}$ & $2.92 \pm 0.05^{\mathrm{a}}$ & $11.67 \pm 0.26^{\mathrm{c}}$ \\
\hline 1 & 25 & $21.31 \pm 0.18^{\mathrm{c}}$ & $59.88 \pm 2.60^{\mathrm{c}}$ & $64.08 \pm 2.60^{\mathrm{c}}$ & $63.96 \pm 2.58^{\mathrm{b}}$ & $13.87 \pm 0.21^{\mathrm{c}}$ & $2.78 \pm 0.04^{\mathrm{a}}$ & $13.00 \pm 0.37^{\mathrm{b}}$ \\
\hline $2-3$ & 25 & $25.29 \pm 0.25^{\mathrm{b}}$ & $62.44 \pm 2.65^{\mathrm{b}}$ & $68.12 \pm 2.85^{\mathrm{b}}$ & $64.84 \pm 2.61^{\mathrm{b}}$ & $14.25 \pm 0.31^{\mathrm{ab}}$ & $2.74 \pm 0.04^{\mathrm{a}}$ & $13.21 \pm 0.39^{\mathrm{b}}$ \\
\hline 4 & 104 & $33.38 \pm 0.38^{\mathrm{a}}$ & $68.51 \pm 2.82^{\mathrm{a}}$ & $74.56 \pm 3.14^{\mathrm{a}}$ & $68.94 \pm 2.73^{\mathrm{a}}$ & $14.79 \pm 0.33^{\mathrm{ab}}$ & $2.94 \pm 0.06^{\mathrm{a}}$ & $15.19 \pm 0.41^{\mathrm{a}}$ \\
\hline
\end{tabular}

a, b, c, means on the same column with different superscripts within the specified dentition group are significantly different $(\mathrm{P}<0.05)$; $\mathrm{BW}=$ Body weight; CG = Chest girth; BL = Body length; HW = Height at wither; EL = Ear length; BCS = Body condition score; PW = Pelvic width; $* *=\mathrm{P}<0.01 ; *=\mathrm{P}<0.05 ;$ ns= non-significant 
Table 3. Live weight and linear measurements of the different age groups in male Borana goats

\begin{tabular}{cccccccccc}
\hline Effect & $\mathrm{N}$ & $\mathrm{BW}$ & $\mathrm{BL}$ & $\mathrm{CG}$ & $\mathrm{HW}$ & $\mathrm{PW}$ & $\mathrm{SC}$ & $\mathrm{EL}$ & BCS \\
\hline Overall & 58 & $26.26 \pm 1.27$ & $63.36 \pm 1.13$ & $67.64 \pm 1.15$ & $66.64 \pm 0.04$ & $13.24 \pm 0.43$ & $22.84 \pm 0.48$ & $14.12 \pm 0.19$ & $2.85 \pm 0.05$ \\
\hline $\mathrm{R}^{2}$ & & 72.99 & 62.4 & 59.76 & 52.33 & 45.62 & 35.88 & 5.69 & 11.69 \\
\hline $\mathrm{CV}$ & 18.38 & 8.56 & 8.42 & 8.79 & 14.31 & 11.81 & 9.91 & 16.21 \\
\hline Dentition & $* * *$ & $* * *$ & $* * *$ & $* * *$ & $* * *$ & $* * *$ & $* * *$ & $* * *$ \\
\hline $0-1$ & 44 & $22.68 \pm 0.26$ & $59.80 \pm 0.83$ & $64.41 \pm 0.82$ & $63.41 \pm 0.84$ & $12.32 \pm 0.39$ & $21.68 \pm 0.45$ & $13.93 \pm 0.21$ & $2.80 \pm 0.05$ \\
\hline $2-4$ & 14 & $40.27 \pm 1.80$ & $74.57 \pm 1.84$ & $79.64 \pm 1.59$ & $76.79 \pm 1.50$ & $16.13 \pm 0.55$ & $26.82 \pm 0.64$ & $14.71 \pm 0.38$ & $3.06 \pm 0.13$ \\
\hline
\end{tabular}

BW = Body weight; CG = Chest girth; BL = Body length; HW = Height at wither; EL = Ear length; BCS =Body condition score; PW = Pelvic width; $\mathrm{SC}=$ Scrotal circumference $* * *=\mathrm{P}<0.001$

$\mathrm{a}, \mathrm{b}, \mathrm{c}$, means on the same column with different superscripts within the specified dentition group and sex are significantly different $(\mathrm{P}<0.05)$; $\mathrm{BW}=$ Body weight; $\mathrm{BL}=$ Body length; $\mathrm{CG}=$ Chest girth; HW = Height at wither; EL = Ear length; $\mathrm{BCS}=$ Body condition score; $\mathrm{PW}=\mathrm{Pelvic}$ width; $\mathrm{SC}=$ scrotal circumference $* * *=\mathrm{P}<0.001 ; * *=\mathrm{P}<0.01 ; *=\mathrm{P}<0.05 ;$ ns= non-significant

Table 4. Least-squares means for body quantitative traits as affected by sex.

\begin{tabular}{ccccccccc}
\hline Effect & BW $(\mathrm{kg})$ & $\mathrm{BL}(\mathrm{cm})$ & $\mathrm{CG}(\mathrm{cm})$ & $\mathrm{HW}(\mathrm{cm})$ & $\mathrm{EL}(\mathrm{cm})$ & $\mathrm{BCS}$ & $\mathrm{PW}(\mathrm{cm})$ & SC \\
\hline Overall & $28.03 \pm 0.63$ & $64.48 \pm 1.99$ & $69.32 \pm 1.99$ & $67.23 \pm 1.87$ & $14.2 \pm 0.27$ & $2.88 \pm 0.07$ & $13.77 \pm 0.41$ & $24.25 \pm 0.53$ \\
\hline $\mathrm{R}^{2}$ & 68.1 & 62.35 & 67.01 & 66.34 & 7.65 & 6.78 & 26.57 & 35.88 \\
\hline $\mathrm{CV}$ & 17.49 & 7.48 & 7.08 & 7.48 & 11.06 & 15.35 & 13.61 & 11.81 \\
\hline Sex & $*$ & $*$ & $*$ & $*$ & $\mathrm{~ns}$ & $\mathrm{~ns}$ & $\mathrm{~ns}$ & \\
\hline Females & $24.6 \pm 0.23^{\mathrm{b}}$ & $61.79 \pm 2.65^{\mathrm{b}}$ & $66.62 \pm 2.79^{\mathrm{b}}$ & $64.37 \pm 2.57^{\mathrm{b}}$ & $14.09 \pm 0.26$ & $2.84 \pm 0.05$ & $13.27 \pm 0.36$ & \\
\hline Males & $31.47 \pm 1.03^{\mathrm{a}}$ & $67.18 \pm 1.33^{\mathrm{a}}$ & $72.02 \pm 1.2^{\mathrm{a}}$ & $70.1 \pm 1.17^{\mathrm{a}}$ & $14.32 \pm 0.29$ & $2.93 \pm 0.09$ & $14.21 \pm 0.47$ & $24.25 \pm 0.53$ \\
\hline
\end{tabular}

BW = Body weight; CG = Chest girth; $\mathrm{BL}=$ Body length; $\mathrm{HW}=$ Height at wither; $\mathrm{EL}=$ Ear length; $\mathrm{BCS}=$ Body condition score; $\mathrm{PW}=$ Pelvic width; $\mathrm{SC}=$ Scrotal circumference $*=\mathrm{P}<0.05$

The result revealed that sex is an important source of variation for live body weight and linear body measurements. Most of the linear body measurements were significant $(\mathrm{p}<0.05)$ between sexes except ear length, body condition score and pelvic width. This indicates that, sexual dimorphism was observed in most of quantitative traits. Male goats were consistently higher than female goats in all quantitative traits except PW, which is slightly higher for female goats (Table 4).

\subsection{Correlation Coefficients}

The correlation coefficients indicating the relationship between the live body weight and linear body measurements in female and male Borana goats are presented in Table 5 and 6, respectively. Most of the parameters considered had positive and significant correlation with live body weight. For both sexes, chest girth had the highest and significant $(\mathrm{P}<0.01)$ correlation with body weight. It explains about $87 \%$ and $96 \%$ of the variation in body weight in females and males goats, respectively. This implies that measurement of chest girth could be fairly used to estimate body weight in Borana goats. The current results are in concurrent with the findings for Red Sokoto [12] and Borno goats [13]. The better association of body weight with chest girth was possibly due to relatively large contribution in body weight by heart girth which consists of bones, muscles and viscera [14]. A higher genetic correlation between body weight and chest girth was reported in Bos taurus cattle [15]. Looking at the correlation of coefficients males showed higher tendency of relationship between body weight and linear measurements than the females. This indicates that on the basis of linear body measurements, body weight could be more accurately predicted in males than in females. This finding is in concurrent with previous studies [13], but in variance with [12].

\subsection{Fitted Regression Model}

Stepwise multiple regressions were carried out in order to predict body weight from linear measurements which is depicted in Table 7 and 8. In estimation of body weight from body measurements in female and male Borana goats 6 and 7 body measurements, respectively were considered. All the linear measurements were fitted into the model through stepwise elimination procedure. In female, the three body measurements that best fit the model are CG, BL and BCS accounting for $95 \%$ of the total live weight variation. The addition of other measurements to the chest girth would result in significant improvement in accuracy of prediction even though the extra gain was small. Likewise, the three body measurements that best fit the model in males are BL, CG and BCS explaining about 97\% of the variation in live weight. The use of combination of chest girth, head length and width of hindquarter measurements for selection and breeding in West Africa dwarf sheep is suggested [16]. On the other hand, [17] indicated that chest girth predict body weight more accurately in Yankasa sheep breed. This implies that live body weight prediction equations form linear measurements vary from species to species and between breeds of the same species. 
Table 5. Correlation between various body measurements in female Long-eared Somali/ Borana goats

\begin{tabular}{|c|c|c|c|c|c|c|c|}
\hline Trait & BW & BL & CG & HW & PW & EL & BCS \\
\hline BW & & $0.84 * *$ & $0.87 * *$ & $0.71^{* *}$ & $0.83^{* *}$ & $0.41^{* *}$ & $0.22 * *$ \\
\hline $\mathrm{BL}$ & & & $0.81^{* *}$ & $0.74 * *$ & $0.79 * *$ & $0.39 * *$ & $0.10 \mathrm{~ns}$ \\
\hline CG & & & & $0.74 * *$ & $0.82 * *$ & $0.43 * *$ & $0.13 \mathrm{~ns}$ \\
\hline HW & & & & & $0.71 * *$ & $0.37 * *$ & $0.01 \mathrm{~ns}$ \\
\hline PW & & & & & & $0.43 * *$ & 0.19* \\
\hline EL & & & & & & & $0.007 \mathrm{~ns}$ \\
\hline BCS & & & & & & & \\
\hline
\end{tabular}

** $=$ P < 0.01, * = P < 0.05; BL=Body Length; CG= Chest Girth; HW= Height at wither; PW = Pelvic Width; EL=Ear length; BCS= Body Condition Score

Table 6. Correlation between various body measurements in male Borana goats

\begin{tabular}{|c|c|c|c|c|c|c|c|c|}
\hline & BW & $\mathrm{BL}$ & CG & HW & PW & SC & EL & BCS \\
\hline BW & & $0.91 * *$ & $0.96 * *$ & $0.93^{* *}$ & $0.79 * *$ & $0.79 * *$ & $0.45^{* *}$ & $0.43^{* *}$ \\
\hline $\mathrm{BL}$ & & & $0.88 * *$ & $0.90 * *$ & $0.78^{* *}$ & $0.78^{* *}$ & $0.41 * *$ & $0.34^{* *}$ \\
\hline CG & & & & $0.95^{* *}$ & $0.76^{* *}$ & $0.85^{* *}$ & $0.50 * *$ & $0.37 * *$ \\
\hline HW & & & & & $0.73^{* *}$ & $0.84^{* *}$ & $0.52 * *$ & $0.39 * *$ \\
\hline PW & & & & & & $0.69 * *$ & $0.44^{*}$ & $0.51^{* *}$ \\
\hline SC & & & & & & & $0.54 * *$ & $0.38 * *$ \\
\hline EL & & & & & & & & $0.21^{\text {ns }}$ \\
\hline BCS & & & & & & & & \\
\hline
\end{tabular}

**= P < 0.01, * = P < 0.05; BL = Body length; CG = Chest girth; HW = Height at wither; PW = Pelvic width; SC = Scrotal circumference; EL

$=$ Ear length; $\mathrm{BCS}=$ Body condition core

Table 7. Regression equation in female Borana goats

\begin{tabular}{ccccccc}
\hline Equations & Intercept & $\beta 1$ & $\beta 2$ & $\beta 3$ & $\mathrm{R}^{2}$ & \multicolumn{2}{c}{$\mathrm{R}^{2}$ Change } \\
\hline CG & -37.758 & 0.96 & - & - & 0.910 & 0.00 \\
\hline BL + CG & -47.39 & 0.54 & 0.60 & - & 0.950 & 0.076 \\
\hline BL+ CG + BCS & -49.724 & 0.52 & 0.60 & 1.12 & 0.952 & 0.004 \\
\hline
\end{tabular}

CG = Chest Girth; BL = Body Length; BCS = Body Condition Score

Table 8. Regression equation in male Borana goats

\begin{tabular}{ccccccc}
\hline Equations & Intercept & $\beta 1$ & $\beta 2$ & $\beta 3$ & $\mathrm{R}^{2}$ & \multicolumn{2}{c}{$\mathrm{R}^{2}$ Change } \\
\hline CG & -37.73 & 0.94 & - & - & 0.941 & 0.00 \\
\hline BL + CG & -42.99 & 0.50 & 0.49 & - & 0.966 & 0.025 \\
\hline BL+ CG + BCS & -45.64 & 0.45 & 0.47 & 1.13 & 0.977 & 0.011 \\
\hline
\end{tabular}

$\mathrm{CG}=$ Chest girth; $\mathrm{BL}=$ Body length; $\mathrm{BCS}=$ Body condition score

\section{Conclusions}

This study indicated that Borana goats are superior to other indigenous goat breeds in many of the quantitative traits considered. Most of the linear body measurements have significant correlation with live body weight. Considering ease of measurement, CG could be used in performance recordings and bridge the gaps still present in keeping the performance of the breed to facilitate within breed selection scheme. Male selection based on SC could at same time improve animals for better body weight.

\section{Competing Interests}

The authors declare that they have no competing interests

\section{Authors' Contributions}

E.Z field data collection, analyzed data and wrote the paper; B. $\mathrm{N}$ involved in data collection, revision and edition of the manuscript, G.T. involved in data collection. All authors read and approved the final manuscript. 


\section{Acknowledgements}

The authors are very grateful to the OARI for the financial support. Researchers and technical assistants participated in data collection are also acknowledged.

\section{REFERENCES}

[1] Peacock, C., 2005. Goats-A pathway out of poverty. Small Rumin Res, 60: 179-186

[2] FARM Africa, 1996. Goat types of Ethiopia and Eritrea: physical description and management systems. International Livestock Research Institute, Addis Ababa, Ethiopia.

[3] Sebisibe, A., 2006. Meat Quality of selected Ethiopian goats genotypes under varying nutritional conditions $\mathrm{PhD}$ thesis. University of Pretoria, Animal and Wildlife Sciences department.

[4] Ayalew, W., 2000. Do smallholder farmers benefit more from cross-bred (Somali $x$ Anglo Nubian) than from indigenous goats? $\mathrm{PhD}$ thesis. Georg-August University of Göttingen, Germany.

[5] FAO (Food and Agriculture Organization), 2007. The State of the World's Animal Genetic Resources for Food and Agriculture. Rome; 2007.

[6] Winrock International, 1992. Assessment of Animal Agriculture in Sub-Saharan Africa. Winrock International for Agricultural Development. Morrilton Arkansas, USA.

[7] Wilson, R.T., Durkin, J.W., 1984. Age at first permanent incisors eruption in indigenous goats and sheep in semi-arid Africa. Livestock Prod Sci, 11: 451- 45.

[8] Hassamo, H.E., Owe, J.B., Farid, M.F.A., 1986. Body condition score in fat tailed Awassi sheep under range conditions. Res Dev Agri, 3: 99-104.

[9] SAS (Statistical Analysis System), 2003. SAS Institute Inc. Cary. North Carolina, USA.

[10] Banerji R., 1984. Effect of solar radiation on biochemical constituents of blood in goats of different coat colors. Livestock-Adviser, 9:34-38.

[11] McManus, C., Louvandini, H., Paim, T., Martins, R. S. Barcellos, J. O., Cardoso, C., Guimarães, R. F., Santana, O.A., 2011. The challenge of sheep farming in the tropics: aspects related to heat tolerance. R Bras Zootec, 40 (supl. Especial):107-120.

[12] Adeyinka, I. A., Mohammed, I.D., 2006. Accuracy of body weight prediction in Nigerian Red Sokoto goats raised in north eastern Nigeria using linear body measurement. Pakistan J Biological Sci, 9: 2828-2830.

[13] Hassan, A., Ciroma, A., 1992. Body weight measurements relationship in Nigerian Red Sokoto Goats In: Small Ruminant Research and Development in Africa proceedings of the First biennial Conference of the African Small Ruminant Research Network (ed.): B. Rey, S.H. b. Lebbie, L. Reynolds, ILRAD, 10-14 December 1990, Nairobi, Kenya.
[14] Thiruvenkadan, A. K., 2005. Determination of best-fitted regression model for estimation of body weight in Kanni Adu kids under farmer's management. Livest Res Rural Dev, 17: 85. http://www.lrrd.org/lrrd17/7/thir17085.htm.

[15] Afolayan, R.A., 2003. Genetics of growth and development in cattle. PhD thesis. University of Adelaide, SA, Australia.

[16] Sowande, O. S., Sobola, O. S., 2008. Body measurement of West Africa dwarf sheep as parameters for estimation of live weight. Trop Health Prod, 40: 433-439.

[17] Afolayan, R.A., Adeyinka, I. A., Lakpini, C. A.M., 2006. The estimation of live weight from body measurements in Yankasa sheep. Czech J Anim Sci, 51: 343-348

[18] Otoikhian, C., Akporhuarho, O., Oyefia, V. E and Isidahomen, C. E., 2008. Body measurement parameters as a function of assessing body weight in goats under on-farm research environment. Department of Animal Science, Faculty of Agriculture, Ambrose Alli University, P. M. B. 14, Ekpoma, Edo State, Nigeria. African Journal of General Agriculture pp1595-6984.

[19] Mekasha, Y., 2007. Reproductive Traits in Ethiopian Male Goats. With special reference to breed and nutrition. Swidish University of Agricultural Science, Uppsala, Sweden. (Ph.D. Dissertation).

[20] Alemayehu, M., 1998. The Borana and the 1991-1992 Drought: A rangeland and livestock resource study. Institute for Sustainable Development and French Catholic Committee against Hunger and for Development, Addis Ababa, Ethiopia.

[21] Coppock, D. L., 1994. The Borana plateau of southern Ethiopia: synthesis of pastoral research development and changes, 1980-90. ILCA (International Livestock Centre for Africa): Addis Ababa, Ethiopia.

[22] Ayana, A. and Oba, G. 2007. Relating long-term rainfall variability to cattle population dynamics in communal rangelands and a government ranch in southern Ethiopia. Agricultural Systems 94: 715-175.

[23] Gemedo, D. T., Brigitte, L. M. and Johannes, I. 2006 Encroachment of woody plants and its impact on pastoral livestock production in the Borana lowlands, southern Oromia, Ethiopia. East African Wild Life Society, African Journal of Ecology, 44:237-246. 